\title{
The Instensity Measurement and Noise Mapping in Fatty Acid Plant Area at PT. XYZ
}

\section{Chalis Fajri Hasibuan, Sutrisno, and Benni Pranatal}

Industrial Engineering Department, Faculty of Engineering, Universitas Medan Area, Medan, Indonesia

\begin{abstract}
PT. XYZ is a factory engaged in processing of palm oil derivatives in producing a fatty acid. The machines used in the processing process at PT. XYZ KIM II Mabar generate the noise. This research aimed to find out the existing noise level and noise mapping, also the proposal of noise control on the production floor. Then, the data collection method conducted through observation using the equivalent noise level (Leq) method and noise mapping was through surfer 14. The data collection conducted in 16 points on the production floor. Furthermore, the result and noise distribution pattern showed that the high noise level was in several points, those were point 5 (85.77); point 6 (86.82); point 7 (86.33), point 8 (88.18); point 10 (86.96); point 13 (86.85); point 14 (87.67). The allowed threshold value refers to the Decree of the Minister of Manpower and Transmigration No.Per.13/MEN/X/2011 is $85 \mathrm{~dB}$. Thus, the company needs to perform noise control among others by using engineering control or administrative control such as barrier usage, regularly and scheduled machine maintenance to prevent and decrease the effect of the noise
\end{abstract}

Keyword: Equivalent Noise Level, Noise Mapping, Noise Reduction, Noise Control, Surfer 14

\begin{abstract}
Abstrak. PT. XYZ merupakan pabrik pengolahan turunan minyak kelapa sawit yang memproduksi fatty acid/asam lemak. Dalam proses pengolahannya PT. XYZ KIM II Mabar menggunakan mesin-mesin yang menimbulkan kebisingan. Penelitian ini bertujuan untuk mengetahui tingkat kebisingan yang ada dan pemetaan kebisingan serta usulan pengendalian kebisingan di lantai produksi. Metode pengumpulan data secara observasi dengan metode perhitungan tingkat kebisingan ekuivalen (Leq) dan pemetaan kebisingan dengan surfer 14. Pengumpulan data dilakukan di 16 titik yang ada di lantai produksi. Hasil penelitian dan pola sebaran kebisingan menunjukkan tingkat kebisingan yang tinggi di beberapa area yaitu titik 5 (85.77), titik 6 (86.82), titik 7 (86.33), titik 8 (88.18), titik 10 (86.96), titik 13 (86.85), titik 14 (87.67). Nilai ambang batas yang dizinkan berdasarkan Peraturan Menteri Tenaga Kerja Dan Transmigrasi Republik Indonesia Nomor PER.13/MEN/X/2011 adalah sebesar 85 dB. Dengan demikian perusahaan perlu melakukan pengendalian kebisingan antara lain dengan menggunakan engineering control ataupun administrative control seperti penggunaan barrier/penghalang, pemeriksaan mesin-mesin yang teratur dan terjadwal untuk mencegah dan mengurangi akibat dari kebisingan tersebut
\end{abstract}

Kata Kunci : Tingkat Kebisingan Ekuivalen, Pemetaan Kebisingan, Pengurangan Kebisingan, Pengendalian Kebisingan, Surfer 14

Received 20 January 2020 | Revised 22 February 2020 | Accepted 27 February 2020

\footnotetext{
*Corresponding author at: Industrial Engineering Department, Faculty of Engineering, Universitas Medan Area, Medan, Indonesia 


\section{Introduction}

Noise in the industry has long been a concern and a problem. Noise exposure in the workplace is estimated at 120 million people have hearing loss in the United States, in 1981 more than 9 million people exposed to noise at work at the level of $85 \mathrm{~dB}$ or more every day, at in 1990 this figure had risen to 30 million, mostly workers in the manufacturing industry, while Germany and other developing countries as many as $4-5$ million people, $12-15 \%$ of all workers are exposed to noise at level of $85 \mathrm{~dB}$ or more [1]

Based on Regulation of The Minister Of Health Of The Republic Of Indonesia Number 70 Of 2016 Concerning Standards And Requirements For The Health Of Industrial Work that the noise threshold value is and the Minister of Manpower and Transmigration No.Per.13/MEN/X/2011 is $85 \mathrm{db}$ (A) [2],[3]

Noise levels that exceed threshold values can be encouraging the onset of hearing loss and the risk of damage to the ear are good temporary or permanent after being exposed for a certain period of time without use of adequate protection [4] . This potential risk drives the government in various countries make a regulation that limits the exposure of workers' votes industry [5] In some industries there are various noise intensities, for example [6]:

1. $85-100 \mathrm{~dB}$ available in textile factories and fatty acid plant, mechanical workplaces such as milling machines, the use of pressurized air, electric drills, mechanical saws.

2. 100-115 dB available in factories. canning, boiler room, drill.

3. 115-130 dB are available on large diesel engines, turbo engines, compressors, sirens.4.130$160 \mathrm{~dB}$ are available on jet engines, blasting rockets.

In supporting the production process to meet the demands of increasing productivity and decreasing labor, the PT. XYZ has implemented mechanization systems on industrial tools and machines that have the potential to cause noise. The noise can disturb the work environment and spread through the air to the workforce. Some complaints arising from noise that occur based on interviews conducted with several employees, namely disruption of work concentration, lack of comfort at work and disturbed communication.

Noise problems were found in the Fatty Acid Plant production section, that is, after the preliminary study by conducting initial measurements it was found that the noise level of the production floor area ranged from 80 to $90 \mathrm{~dB}$ for 8 working hours. It can be seen that this exceeds the permissible noise threshold value in the Indonesian government regulation on industrial estates, namely the permissible noise threshold value (NAV) of $85 \mathrm{~dB}$ for 8 working hours. 


\section{Research Method}

This type of research is descriptive research (descriptive research) where research aims to describe sitematically, factually and accurately about the facts and properties of a particular object or population. The type of descriptive research in question is survey research. This research is called survey research because in this study conducted collecting data and information directly from operators who work in the noise area. This research is also an action review that is research that aims to get a solution that will be applied to the company as a form of improvement of the original system.

The data collection mechanism is:

1. Prepare the Sound Level Meter tool.

2. Measuring the noise level at 16 points in accordance with KepMenLH N0.48 / MenLH / 11/1996 [7]

3. Interviews of several employees

4. Calculation of noise level

5. Mapping of noise levels with surfers

Measurement refers to KEPMENLH No.48 / MenLH / 11/1996. Calculation of Leq data for 1 minute, calculated using the formula:

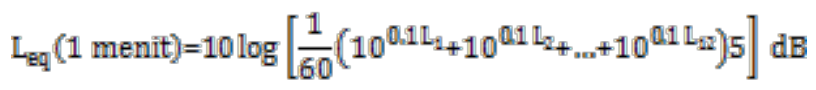

Calculation of Leq data for 4 minutes, calculated using the formula:

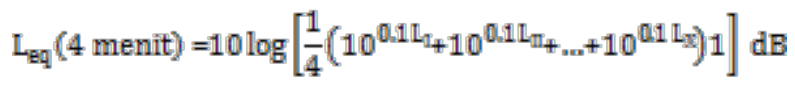

After the 4 minute Leq value is obtained, then it is entered in the table. Data entered in the measurement column L1 through L7. If the data table is complete in accordance with Minister of the Environment Decree No. 48 / MenLH / 11/1996 concerning Noise Level Standards, the average value of Leq measurements will be obtained for 24 hours. For daytime Leq (Ls) measurements are taken from 06.00-22.00 hours, while nighttime Leq (LM) measurements are carried out from 22.00-06.00. The results of these measurements are added to the weighting factor, which is $5 \mathrm{~dB}(\mathrm{~A})$.

For day and night Leq can be calculated by the formula:

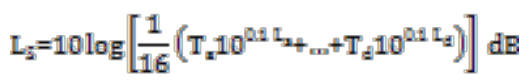

And

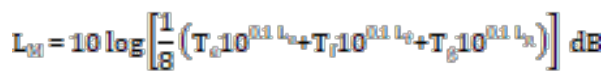


The measurement results during the day and night are then combined to get the noise level in one day with decibels. Following is the formula used:

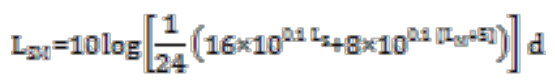

\section{Result and Discussion}

\subsection{Equivalent Noise Level Calculation}

After measuring, the average noise measurement data are obtained as follows:

Table 1 Average Noise Level Measurement Results (dB)

\begin{tabular}{lllllllll}
\hline & L1 & L2 & L3 & L4 & L5 & L6 & L7 & Average \\
\hline Point 1 & 82.43750 & 82.38750 & 82.44792 & 82.51458 & 82.48750 & 82.48542 & 82.47292 & 82.46190 \\
Point 2 & 84.01250 & 83.97292 & 84.09792 & 84.09375 & 84.07500 & 84.07083 & 84.08333 & 84.05804 \\
Point 3 & 85.13333 & 85.18542 & 85.17917 & 85.2000 & 85.17708 & 85.16458 & 85.17083 & 85.17292 \\
Point 4 & 84.75000 & 84.79792 & 84.77917 & 84.85208 & 84.81458 & 84.76875 & 84.77083 & 84.79048 \\
Point 5 & 85.73750 & 85.72083 & 85.72917 & 85.81667 & 85.77500 & 85.77292 & 85.75000 & 85.75744 \\
Point 6 & 86.79167 & 86.79792 & 86.81458 & 86.85208 & 86.82708 & 86.78333 & 86.83125 & 86.81399 \\
Point 7 & 86.27500 & 86.27292 & 86.31875 & 86.36667 & 86.34792 & 86.32708 & 86.34583 & 86.32202 \\
Point 8 & 88.08958 & 88.18333 & 88.13958 & 88.17083 & 88.19167 & 88.13750 & 88.19583 & 88.15833 \\
Point 9 & 83.81042 & 83.86250 & 83.86667 & 83.82083 & 83.74167 & 83.84375 & 83.87083 & 83.83095 \\
Point 10 & 86.89375 & 86.95625 & 86.93125 & 86.94792 & 86.94583 & 86.95625 & 86.98333 & 86.94494 \\
Point 11 & 85.00625 & 84.97500 & 85.00833 & 85.03958 & 85.03958 & 85.02500 & 85.05208 & 85.02083 \\
Point 12 & 82.68333 & 82.67083 & 82.70833 & 82.68333 & 82.71458 & 82.70000 & 82.70417 & 82.69494 \\
Point 13 & 86.81250 & 86.80833 & 86.87708 & 86.86250 & 86.87292 & 86.82292 & 86.84792 & 86.84345 \\
Point 14 & 87.78958 & 87.80625 & 87.87292 & 87.86875 & 87.84792 & 87.84583 & 87.88750 & 87.84554 \\
Point 15 & 84.96458 & 84.99375 & 85.03750 & 85.01042 & 85.03333 & 84.97917 & 84.98958 & 85.00119 \\
Point 16 & 83.97917 & 84.00208 & 84.07083 & 84.03542 & 84.08542 & 84.04583 & 84.03542 & 84.03631 \\
\hline
\end{tabular}

Equivalent Noise Level Calculation, From the calculation of $L_{p n}$ (1 minute) $82.4198 \mathrm{~dB}$ (a) data is obtained, then the data is entered into $L_{e n}$ (4 minute)to obtain $82.4433 \mathrm{~dB}$ data ( A). The results of $L_{e n}$ ( 4 minute)for each point from L1 to L7 are presented in the following table:

Table 2 Equivalent Noise (dB) (Leq)

\begin{tabular}{lcccccccc}
\hline \multirow{2}{*}{$\begin{array}{c}\text { Measurement } \\
\text { Point }\end{array}$} & L1 & L2 & L3 & L4 & L5 & L6 & L7 & Average \\
\cline { 2 - 9 } & 82.44330 & 82.39145 & 82.45338 & 82.52158 & 82.49398 & 82.49241 & 82.48023 & 82.46805 \\
Point 1 & 84.02494 & 83.98187 & 84.11403 & 84.11034 & 84.08980 & 84.08802 & 84.09944 & 84.07263 \\
Point 2 & 85.13540 & 85.18823 & 85.18312 & 85.20360 & 85.17672 & 85.16847 & 85.17265 & 85.17546 \\
Point 3 & 84.78720 & 84.82906 & 84.81754 & 84.89296 & 84.85465 & 84.80826 & 84.80617 & 84.82798 \\
Point 4 & & & & & & & &
\end{tabular}




\begin{tabular}{lllllllll}
\hline Point 5 & 85.75014 & 85.73331 & 85.74107 & 85.83552 & 85.78841 & 85.78938 & 85.76650 & 85.77205 \\
Point 6 & 86.80291 & 86.80678 & 86.82771 & 86.86692 & 86.84256 & 86.79928 & 86.84762 & 86.82768 \\
Point 7 & 86.28453 & 86.28184 & 86.33112 & 86.38124 & 86.36013 & 86.34224 & 86.35520 & 86.33376 \\
Point 8 & 88.11698 & 88.20769 & 88.16506 & 88.19169 & 88.21295 & 88.16152 & 88.21993 & 88.18226 \\
Point 9 & 84.12603 & 84.17342 & 84.18364 & 84.05888 & 83.95955 & 84.16873 & 84.19294 & 84.12331 \\
Point 10 & 86.90427 & 86.97683 & 86.94949 & 86.96655 & 86.96279 & 86.97240 & 86.99766 & 86.96143 \\
Point 11 & 85.01160 & 84.99080 & 85.01581 & 85.05116 & 85.05112 & 85.03392 & 85.06715 & 85.03165 \\
Point 12 & 82.69354 & 82.68257 & 82.72170 & 82.69323 & 82.72683 & 82.71079 & 82.71553 & 82.70631 \\
Point 13 & 86.81490 & 86.82522 & 86.88229 & 86.86826 & 86.88601 & 86.83558 & 86.85688 & 86.85273 \\
Point 14 & 87.79180 & 87.80280 & 87.87460 & 87.87231 & 86.66455 & 87.84566 & 87.88995 & 87.67738 \\
Point 15 & 84.96868 & 85.00104 & 85.04887 & 85.02072 & 85.05714 & 84.99516 & 85.00098 & 85.01323 \\
Point 16 & 83.97807 & 84.00536 & 84.06889 & 84.03438 & 84.09536 & 84.04533 & 84.03942 & 84.03812 \\
\hline
\end{tabular}

As for the results of the calculation include the following:

1. Calculations for daylight hours $\left(\mathrm{L}_{\mathrm{s}}\right)$ with a time span of 6:00 to 10:00 p.m. obtained a value of "81.57 dB (A)".

2. Calculations for the night $\left(\mathrm{L}_{\mathrm{M}}\right)$ with a time span of 22:00-06.00.00 obtained a value of "82.5" dB (A).

3. The last calculation is to determine the total environmental noise $\left(\mathrm{L}_{S \mathrm{SM}}\right)$ (24 hours) obtained a value of "84.5" dB (A).

For each data presented in the following table:

Table 3. Noise Level (dB) Equivalent (Leq) Total 24 hours

\begin{tabular}{lccc}
\hline \multirow{2}{*}{$\begin{array}{c}\text { Measurement } \\
\text { Point }\end{array}$} & \multicolumn{3}{c}{ Equivalent Noise (dB) (Leq) } \\
\cline { 2 - 4 } Leq Siang $\left(\mathbf{L}_{\mathbf{S}}\right)$ & Leq Malam $\left(\mathbf{L}_{\mathbf{M}}\right)$ & $\mathbf{L}_{\mathbf{S M}}$ \\
\hline Point 1 & 81.57 & 82.5 & 84.5 \\
Point 2 & 83.17 & 84.1 & 86.1 \\
Point 3 & 84.28 & 85.2 & 87.2 \\
Point 4 & 83.94 & 84.8 & 86.9 \\
Point 5 & 84.88 & 85.8 & 87.8 \\
Point 6 & 85.93 & 86.8 & 88.9 \\
Point 7 & 85.43 & 86.4 & 88.4 \\
Point 8 & 87.27 & 88.2 & 90.2 \\
Point 9 & 83.22 & 84.1 & 86.2 \\
Point 10 & 86.05 & 87.0 & 89.0 \\
Point 11 & 84.12 & 85.1 & 87.1 \\
Point 12 & 81.80 & 82.7 & 84.7 \\
Point 13 & 85.95 & 86.9 & 88.9 \\
Point 14 & 86.94 & 87.6 & 89.7 \\
Point 15 & 84.11 & 85.0 & 87.0 \\
Point 16 & 83.12 & 84.1 & 86.1 \\
\hline
\end{tabular}


Based on table 3 can show the equivalent noise level from each measurement point on the production floor of PT. XYZ Making the graph will find out which points have the highest and lowest noise levels.

Based on the data obtained, noise mapping is done using Surfer 14 software, so we can see areas that have high and low noise levels.

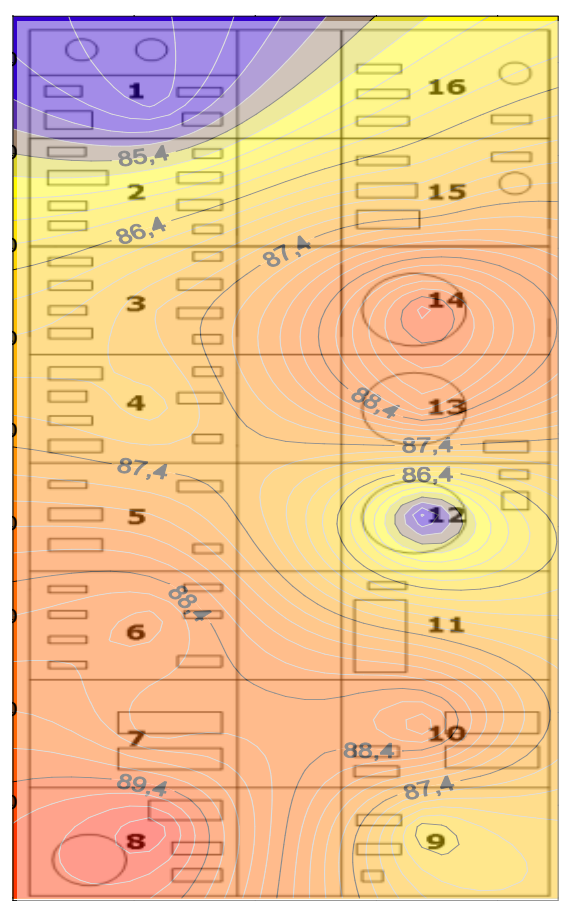

Figure 1 Noise Mapping

Based on Regulation Of The Minister Of Health Of The Republic Of Indonesia Number 70 Of 2016 Concerning Standards And Requirements Of Health Environment Industry that the noise threshold value is $85 \mathrm{db}$ (A) from figure 1 and table 3 is produced from 16 points there are 15 points that exceed government regulations where the noise calculation results range. between 86-90.2 db (A), so it needs to be followed up to be able to reduce the noise

\subsection{Proposed Control of Noise Sources}

\subsubsection{Subtitution}

Reduce noise by replacement of worn engine parts

\subsubsection{Engineering Control}

1. Isolate the machine by making a damper / barrier

2. Lubricating the moving parts 


\subsubsection{Administrative Control}

1. Reducing production capacity by following the design of production capacity set to maintain engine conditions so that the lifetime of the engine is maintained.

2. Rearranging the scheduling system for the inspection of existing machines and pumps such as preventive maintenance, predictive maintenance and corrective maintenance which so far have not been carried out optimally in the hope that the engine conditions can be maintained and work properly so as to reduce the noise level generated from the engine.

3. Rearranging the current employee shift system to reduce the time of noise exposure received by employees.

\subsubsection{Personal Protective Equipment}

Provide a sign board at points that have a high noise level to warn employees to use the required PPE in that area / point.

\section{Conclusion}

The several things that can be conclusions from the discussion of this paper include :

1. Based on the calculation of equivalent noise intensity (Leq) on the production floor of PT. $\mathrm{XYZ}$, it is found that some points exceed the threshold values that have been set in the industrial environment of $85 \mathrm{~dB}$ which refers to Peraturan Menteri Tenaga Kerja Dan Transmigrasi Republik Indonesia Nomor PER.13/MEN/X/2011 Point 2 (86,1), Point 3 (87,2), Point 4 (86.9), Point 5 (87,8), Point 7 (88,9), Point 8 (90,2), Point $9(86,2)$ Point 10 (89), point 11 (87), Point 13 (88,9), point 14 ( 89,7), Point 15 ( 87) and Point 16 ( 86,1).

2. Based on the calculation of 24 hour noise intensity $\left(\mathbf{L}_{\mathbf{S M}}\right)$ then only 2 points meet the specified threshold value, namely point 1 (84.5) and point 12 (84.7) while the other 14 points exceed the threshold value.

3. Based on noise distribution maps with surfer software, it can be seen that there are 14 points that have noise levels that have exceeded the threshold so that further action is needed to reduce noise exposure that occurs.

4. To reduce noise at PT. XYZ can be done by substitution of components that have been damaged, doing engineering control with the description of the barrier, for administrative control by means of one of which is to periodically maintenance and provide personal protective equipment to workers 


\section{REFERENCES}

[1] A. Pradana, "Hubungan Antara Kebisingan dengan Stres Kerja pada Pekerja Bagian Gravity PT. Dua Kelinci,” Unnes Journal of Public Health, 2014.

[2] Ministry of Manpower, "Thershold Value of Physical Factors in The Workplace”, no. 48, 1996.

[3] Peraturan Menteri Kesehatan Republik Indonesia, "Standar dan Persyaratan Kesehatan Lingkungan Kerja Industri,” no. 70, 2016.

[4] Siswati and R. Adriyani, "Hubungan Pajanan Kebisingan dengan Tekanan Darah dan Denyut Nadi pada Pekerja Industri Kemasan Semen,” Jurnal Kesehatan Lingkungan Indonesia., 2017.

[5] A. A. L. I. Abbasi, H. B. U. X. Marri, and M. Nebhwani, "Industrial Noise Pollution and its Impacts on Workers in the Textile Based Cottage Industries: An Empirical Study," vol. 30, no. 1, 2011.

[6] D. F. Ginting, dkk, "Analisis Tingkat Kebisingan Untuk Mereduksi Dosis Paparan Kebisingan di PT. XYZ,” e-Jurnal Teknik Industri FT USU., vol. 2, no. 1, 2013.

[7] KepMen LH, "Baku Tingkat Kebisingan," Kementerian Lingkungan Hidup., no. 48, 1996. 